\title{
Penelitian EFFECTIVENESS OF PRE-HOSPITAL MANAGEMENT TRAINING OF BONE FRACTURE MANAGEMENT ON KNOWLEDGE AND SKILLS OF SOCCER PLAYERS
}

\author{
Ellan Kukuh Nurdiansyah ${ }^{1}$, Janes Jainurakhma ${ }^{2}$, Hardianto $^{3}$ \\ Program Studi Keperawatan Program Sarjana, Sekolah Tinggi IImu \\ Kesehatan Kepanjen ${ }^{123}$
}

\begin{abstract}
This study aims to analyze the effectiveness of training on the knowledge and skills of soccer players about pre-hospital management of fracture management. This study used a pre-experimental approach to the pretest-posttest. The sample in this study was 32 soccer players. The sample collection technique uses purposive sampling. The instrument in this study was a closed-ended questionnaire and observation sheet. The results of statistical tests using the Wilcoxon test with a significance level of 0.05 obtained $p$-value $<0.001$. The results of this study indicate that training with simulation methods about pre-hospital management of fracture management is effective in increasing the knowledge and skills of soccer players, and this knowledge is needed to anticipate disability due to injury from a soccer athlete due to fractures with pre-hospital management done in a good and right way.
\end{abstract}

Keywords: Pre-hospital management, fracture, knowledge, skills, soccer players 


\section{PREFACE}

Fracture is a condition of broken bones and broken continuity of bone tissue and/or cartilage which is generally caused by forced robbery, injury, both directly and can result in bone losing its function as a supporting body (Storheim, 2014). Fractures can occur in various places in the skeletal system, especially in the lower limb which has the function of mobilizing so that the human body can move from one place to another. Fractures can be caused by pathological conditions other than traumatic factors (WHO, 2014). In general, fractures can be divided into several classifications, one of which is based on the relationship of bone with surrounding tissue, namely open fractures and closed fractures Solomon, 2010; Mahatha, 2015).

Sports injuries are many types and can be grouped based on place, process and time of occurrence of injury. Based on the place of occurrence, sports injuries are divided into soft tissue injuries and hard tissue injuries. Soft tissue injuries are injuries to muscles, nerves, tendons, ligaments, skin, and blood vessels. While hard tissue injury is an injury to the bone, in the form of cracks or fractures entirely (Triono, 2015).

World Health Organization, fracture cases occurred in the world of approximately 13 million people in 2008 , with a prevalence rate of $2.7 \%$. While in 2009 there were approximately 18 million people who had broken bones with a prevalence of $4.2 \%$. In 2010 it increased to 21 million people with a prevalence rate of $3.5 \%$. The occurrence of these fractures includes soccer. Football is one sport that requires power and technique, including kicking the ball, holding the ball, dribbling, trickery, heading, throwing, throwing, throwing (goalkeeping) (Sukirno, 2014 ), but if not done with good technique can cause injury to the players. The incidence rate of injury in early soccer athletes is mentioned; neck injury $10.1 \%$, right shoulder $7.7 \%$, left shoulder $1.8 \%$, right and left shoulder $1.8 \%$, right elbow $3.6 \%$, left elbow $3.0 \%$ right and left elbow $1,2 \%$, right wrist
$8.9 \%$, left wrist $5.4 \%$, right and left wrist $1.8 \%$, back $4.8 \%$, waist $4.2 \%$, pelvis $1.8 \%$, knee 11 , $8 \%$, and ankle joints $21.0 \%$ (Erwan, 2015), while the incidence of fractures in soccer players $(0.7 \%)$ (Soheil \& Hassan, 2018).

Sports injuries can be caused by internal and external factors, as stated by (Fathan, 2010); (Rizall, 2017). Sports injuries, among others, can be caused by collisions during training or matches, which cause fractures, muscle weakness, overuse or poor infrastructure. Activities that can cause sports injuries are training (30\%), competition (35\%), physical education classes (20\%), and informal play (15\%) (Hamidie, 2011); Kurnia, 2018). Football is a complex sport and is at risk of physical injury to its players (Soheil \& Hassan, 2018), injuries caused by soccer generally occur in the musculoskeletal system, namely tendons, muscles, ligaments, skin, and bones (Pratiwi, 2011; Marlina, 2016). Accidents in the musculoskeletal system must be dealt with quickly and appropriately. If it will not cause an injury that is getting worse and can trigger bleeding. Other impacts that occur can result in bone deformities or disability and even death. First aid for injured victims of the musculoskeletal system requires splint dressing (Thygerson, 2009; Desiartama et al, 2017). The splint dressing can be carried out by all trained persons (Boswick, 2012; Nurarif, 2015). Deficiency is a variety of actions and efforts to rest a broken part. Midwifery is a first aid method for trauma to the musculoskeletal system to rest (immobilize) the injured body part by using a device. Splinting can support or hold parts of the body so they do not shift or change from the desired position. Thus avoiding parts of the body so as not to shift from its place and reduce pain (Fakhurrizal, 2015).

The first action that can be done in helping a broken bone is by doing a splinting, that is really needed as an action and an effort to rest the broken part (Saputro, 2017). The condition of the patient who needs first aid in the splint dressing on the victim of a good fracture that is avoiding further bleeding and protected from disability is the important 
point that a first helper must have an adequate scientific basis on the skills of handling emergency patients, especially in fracture injuries (Saputri Rizka, 2017). Based on the description above, splint dressing can be done by all trained laypeople. Everyone must be able to do first aid because most people will eventually be in a situation that requires first aid for others or themselves (Thygerson, 2009; Zulkarnain, 2016). Therefore researchers make this an interesting topic for research on the effectiveness of pre-hospital management training on fracture management on the level of knowledge of football players in the MBOIS FC Soccer School (SSB) in Malang Regency.

\section{METHOD}

\section{RESULTS AND DISCUSSION}

Table 1. Characteristics of respondents in terms of age

\begin{tabular}{llll}
\hline No & Age & Frequency & Percentage (\%) \\
\hline 1. $\quad<20$ years & 15 & 46.9 \\
2. $\quad>20$ years & 17 & 53.1 \\
\hline Total & & \\
\hline
\end{tabular}

(Source: Questionnaire primary data at SSB MBOIS FC, December 2019)

Table 2. Level of Football Player Knowledge about pre-hospital management of fracture management before (pretest) training with simulation methods.

\begin{tabular}{llll}
\hline No & Knowledge & Frequency & Percentage (\%) \\
\hline 1. & Enough & 8 & 25 \\
2. & Less & 24 & 75 \\
\hline Total & & 100
\end{tabular}

(Source: Questionnaire primary data at SSB MBOIS FC, December 2019)

Table 3. Level of Football Player Knowledge about pre-hospital management of fracture management (posttest) provided training with simulation methods.

No Knowledge $\quad$ Frequency $\quad$ Percentage (\%)




\begin{tabular}{llll}
\hline 1. & Very good & 30 & 94 \\
2. & good & 2 & 6
\end{tabular}

\begin{tabular}{lll}
\hline Total & 32 & 100
\end{tabular}

(Source: Questionnaire primary data at SSB MBOIS FC, December 2019)

Table 4. Level of Skills (applying) Football Players about pre-hospital management of fracture management (pretest) are given training with simulation methods.

\begin{tabular}{llcc}
\hline No & Skill & Frequency & Percentage (\%) \\
\hline 1. & Less & 32 & 100 \\
\hline Total & & 32 & 100
\end{tabular}

(Source: Questionnaire primary data at SSB MBOIS FC, December 2019)

Table 5. Skill Level (applying) Football Players about pre-hospital management of fracture management (posttest) are given training with simulation methods

\begin{tabular}{llll}
\hline No & Skill & Frequency & $\begin{array}{l}\text { Percentage } \\
(\%)\end{array}$ \\
\hline 1. & Very good & 17 & 53 \\
2. & good & 15 & 47 \\
\hline Total & & \\
\hline
\end{tabular}

(Source: Questionnaire primary data at SSB MBOIS FC, December 2019)

Table 6. Statistical analysis results with Wilcoxon test

\begin{tabular}{lccc}
\hline Knowledge & $\mathbf{N}$ & $\begin{array}{c}\text { Median } \\
\text { (minimum- } \\
\text { maksimum) }\end{array}$ & $\boldsymbol{P}$ \\
\hline Before & 32 & $60(25-70)$ & $<0.001$ \\
After & 32 & $95(85-100)$ &
\end{tabular}

\begin{tabular}{|c|c|c|c|}
\hline Skill & $\mathbf{N}$ & $\begin{array}{l}\text { Median } \\
\text { (minimum-maksimum) }\end{array}$ & $P$ \\
\hline Before & 32 & $0(0-0)$ & $<0.001$ \\
\hline After & 32 & $92(83-100)$ & \\
\hline
\end{tabular}

Statistical tests using the Wilcoxon test with a significance level of 0.05 , obtained data that is a p-value of $<0.001(<0.05)$. So it can be concluded that the initial hypothesis is accepted that the pre-hospital management simulation method for managing fractures is effective in increasing the knowledge and skills of soccer players. 


\section{DISCUSSION}

Research with Pre-hospital Management simulation methods for fracture management is very useful for soccer players. Because if other players have broken bones can do first aid properly and correctly. Because the SSB MBOIS FC soccer player has never done a simulation regarding the first treatment of fracture injuries. It was proven that when football players were told to take the first action on their broken bones, they still could not at all. Therefore it is very necessary for training in the first treatment of fractures (pre-hospital management) to soccer players.

According to Henry (2010); Mudzakir, 2014,) knowledge is influenced by several factors one of which is age, education, work, socioeconomy, information, and experience. In this study, researchers made the experience as a method to determine the level of knowledge of respondents. This is supported by Kasnianingsih (2015) who said that the experience through the simulation method is very pleasant and can allow experiments to take place without the need for an actual environment. This method can also train participants to think critically because all participants are involved in the simulation process and generate positive responses from participants who are slow and lacking in communication.

From the research conducted by researchers, the results showed that the level of knowledge of $\mathrm{C} 1$ and $\mathrm{C} 2$ soccer players SSB MBOIS FC before (pretest) was given training from 32 respondents found that most respondents lack knowledge of 24 respondents $(75 \%)$. While the level of knowledge of C3 soccer player SSB MBOIS FC before (pretest) was given training, it was found that there were 32 respondents $(100 \%)$ less knowledgeable respondents, where the knowledge of SSB MBOIS FC soccer player was influenced by the lack of experience or pre-hospital management training in fracture management.

From the results of the above research based on existing theories and facts, researchers can conclude that there are still many soccer players who have not been optimal in getting training on pre-hospital management of fracture management. This can be influenced by the lack of information obtained and experience that makes soccer players less understand and understand when a fracture occurs.

Research with Pre-hospital Management simulation methods for Broken Bones Management is very useful for soccer players. Because if other players have broken bones can do first aid properly and correctly. It was proven after simulation of the first treatment of fracture injuries they were able to practice independently how to do first aid fracture injuries properly and correctly to avoid complications.

Results after (posttest) training of football players knowledge C1 (knowing) and C2 (understanding), namely 30 respondents categorized Very Good (94\%) and Results after (posttest) training of football players knowledge C3 (applying) is 17 Very good respondents (53\%). This shows that after training with the simulation method the knowledge of soccer players has increased significantly, this can be seen from the results of the posttest which has increased in percentage.

According to Notoatmodjo (2014) knowledge is obtained from one's own experience or others. This happens when someone has got a sense of an object. The process of accepting new behavior in individuals has stages, namely awareness, interest, evaluation, 
trial, adoption. This is in line with what is done by researchers in which research provides training with simulation methods that are expected to be able to increase the knowledge and experience of respondents.

From the results of the discussion above which includes existing theories and facts, the researcher can conclude that there was an increase before the respondent was explained the prehospital management material for fracture management, then exemplified the researcher and tried to practice independently accompanied by the researcher. Methods with practice apply and adapt theories to actual conditions. So that researchers can conclude that there is an increase in knowledge of soccer players after being given training and pre-hospital management simulation of fracture management.

The results of the research analysis using the Wilcoxon test with a significance level $<0.05$ obtained data that is the p-value of $<0.001 \quad(<0.05)$. So it can be concluded that $\mathrm{H} 1$ was accepted, which is a method of a prehospital management simulation of fracture management effective in increasing the knowledge of SSB MBOIS FC football players.

The results above indicate that after being given training with simulation methods, the level of knowledge of soccer players has increased. With the results that knowledge $\mathrm{C} 1$ (knowing) and C2 (understanding), soccer players found 30 respondents categorized very good (94\%) while the remaining 2 respondents were good categories (6\%) and C3 knowledge (applying) ie 17 respondents were also categorized very well $(53 \%)$ while the remaining 15 respondents were categorized as good (47\%).

This increase in knowledge cannot be separated from the provision of training through simulations. In the simulation, there is also a discussion session, and questions and answers to cause feedback from the participants so that they are not bored because they are as young as they are so easily bored. Because they are still in their teens there is a high increase in curiosity so they are enthusiastic about participating in the simulation. So that their knowledge will increase and create a dynamic atmosphere. By the opinion Kasnianingsih (2015) which says that the experience through the simulation method is very pleasant and can allow experiments to take place without the need for an actual environment. This method can also train participants to think critically because all participants are involved in the simulation process and generate positive responses. So that the knowledge of soccer players increases. It can be concluded that the simulation method is effective in increasing the knowledge of soccer players (Wulandari, 2015).

The simulation method is one of the methods that influence the increase in knowledge of soccer players, this method is effective in increasing the knowledge of soccer players wherein the pre-hospital management simulation method the management of fractures in soccer players will be more enthusiastic to gain knowledge and learn firsthand how to handle the first fracture from the initial action to the final action (treatment). It is also able to increase the imagination of soccer players so that they can quickly understand, understand and can do. Besides this method can reduce mistakes when compared to just reading and listening, because participants get a direct and clear picture of observation (Putra, 2015).

\section{CONCLUSIONS AND SUGGESTIONS}


The conclusion of this research is the pre-hospital management training on fractures with simulation methods provided to soccer athletes very effective in improving the knowledge and skills of soccer players, especially in providing first aid in fracture injuries that may occur on the field due to violent impact during the matches. With good knowledge and skills from athletes in the management of fractures is expected to be able to prevent athlete disability, due to proper handling at pre-hospital.

Suggestions submitted by researchers are: 1) it is expected that the results of this study can be used as guidelines for the application of prehospital management training in fracture management for soccer players in the football club environment, soccer competition competitions and the wider community; 2) this research is an input for athletes to increase the knowledge of soccer players about pre-hospital management of fracture management so that it can be applied in the surrounding community and reduce disability due to injury during matches.

\section{REFERENCES}

Desiartama Agus, \& Wien Aryana (2017). Gambaran Karakteristik Pasien Fraktur Femur Akibat Kecelakaan Lalu Lintas Pada Orang Dewasa Di Rumah Sakit Umum Pusat Sanglah. E-Jurnal Medika, Vol. 6 No.5. ISSN: 23031395.

Erwan Nur Arinda. (2015). Analisis Cedera Olahraga Dan Pertolongan Pertama Pemain Sepak Bola. Jurnal. Jurnal Kesehatan Olahraga Surabaya

Fakhrurrizal, A. (2015) Pengaruh pembidaian terhadap penurunan rasa nyeri pada pasien
Kasnianingsih, L. 2015. Penerapan Metode Simulasi Untuk Meningkatkan Hasil Belajar IPS Siswa Kelas V SDN Wunut. Klaten: Universitas Negeri YogyakartaMalaysian Orthopaedic J. 2010;4(3):39.

Kurnia, S.H et. Al. (2018). Faktor-Faktor Yang Melatarbelakangi Pasien Patah Tulang Berobat Ke Pengobatan Tradisional Ahli Tulang Disumedang. Bandung: Fakultas IImu Keperawatan Universitas Padjajaran.

Mahatha,A. R. G. 2015. Manajemen fraktur pada trauma musculoskeletal.

Marlina. (2016). Mobilisasi Pada Pasien Fraktur Melalui Pendekatan Konseptual Model Dorothea E. Orem. Idea Nursing Journal. Issn : 2087-2879

Mudzakir, M. 2014. Pengetahuan Masyarakat Tentang Demam Berdarah Dengue Di Desa Kedungsari Kecamatan Tarokan Kabupaten Kediri. Vol 25 No. 1 Desember.

Notoatmodjo. 2014. Metodologi Penelitian kesehatan. Jakarta: PT. Rineka Cipta November 2017 11.00 Wita.

Nurarif, A.H \& kusuma, H. 2015. Aplikasi asuhan keperawatan berdasarkan diagnose medias \& NANDA NICNOC. Edisi revisi jilid 2. Yogyakarta: media action publishing.

Putra, A. (2015). Perbedaan hasil belajar siswa melalui penggunaan simulasi dengan metode ceramah pada mata pelajaran mengenai surat/dokumen kantor kelas XI AP SMKN 2 Padang. Ekonomi dan Pendidikan, 20-35.

Rizall, Ahmad. 2017. Penatalaksanaan Orthopedi Tekini Untuk Dokter 
E - ISSN : $2722-127 X$

$P-$ ISSN : $2338-4700$

Layanan Primer. Jakarta: Mitra Wacana Media

Saputri Rizka. (2017). Hubungan tingkat pengetahuan balut bidai dengan sikap pertolongan pertama fraktur pada Mahasiswa keperwatan.Di akses 29 Oktober 201721.00 Wita.

Saputro, W.W, (2017), Pengaruh pendidikan kesehatan dengan metode simulasi terhadap pengetahuan masyarakat.

Soheil, H., \& Hassan, D. (2018). A Prospective Study on the Relationship between Sports Injuries and some of the Physical Fitness Factors in Soccer Players. Journal of Physical Education, Health and Sport, 5(1), 14-20.

Storheim K, Zwart JA (2014). Musculoskeletal disorders and the Global Burden of Disease study. Ann

Sukirno. (2014). Kemampuan Lemparan ke dalam pada Sepak Bola. Journal of Physical Education, Health and Sport, 1(1), 60-67.

Triono $\mathrm{P}$, Murinto. Aplikasi pengolahan citra untuk mendeteksi fraktur tulang dengan metode deteksi tepi. J Inform. 2015;9(2):1115-23.

Wulandari, Ika. 2015. Aplikasi Pemodelan dan Simulasi dalam Mengevaluasi Kinerja Instalasi Rawat Darurat RSUD Dr. Soetomo Surabaya.

Zulkarnain Mr. (2016). Kejaian Fraktur Femur Di Ruang Seruni RSUD Dr. M Yunus Bengkulu. Mitra Raflesia Vol. 5 No. 1. Bengkulu. 